\title{
The Difference between Senior Manager Compensation and Salaries of Full-Time Employees in Non-Management Positions on Corporate Governance in Taiwan
}

\author{
Yu-Ting Huang \\ Department of Business Administration, MingDao University, Taiwan \\ Email: ythuang3@mdu.edu.tw
}

How to cite this paper: Huang, Y.-T. (2020). The Difference between Senior Manager Compensation and Salaries of Full-Time Employees in Non-Management Positions on Corporate Governance in Taiwan. Theoretical Economics Letters, 10, 1372-1396. https://doi.org/10.4236/tel.2020.106084

Received: October 28, 2020

Accepted: December 27, 2020

Published: December 30, 2020

Copyright $\odot 2020$ by author(s) and Scientific Research Publishing Inc. This work is licensed under the Creative Commons Attribution International License (CC BY 4.0).

http://creativecommons.org/licenses/by/4.0/

\section{(c) (i) Open Access}

\begin{abstract}
This study examines the impact of differences between senior manager compensation and salaries of full-time employees in non-management positions (DME) on corporate governance evaluation system (CGES). It seeks to understand whether corporate governance can consistently promote the success of company insiders, outsiders, and improve the corporate governance structure's supervision. Empirical results show that DME has a positive influence on CGES in Big 4 CPA firms, which have better corporate governance evaluation levels. Deloitte, PWC, and KPMG have significantly better evaluation ratings of corporate governance. In addition, different types of conglomerate control for DME manager governance and co-governance have greater positive effects. Finally, non-change lead CPA, change concurring CPA, and non-change concurring CPA show that companies have better corporate governance evaluation. To encourage listed companies to attach importance to the level of corporate governance and assist in the effectiveness of capital market operations, a company should review and promptly implement an overall remuneration policy to comply with corporate governance trends. All listed companies can gradually implement and improve corporate governance to assist investors and other companies in understanding their effectiveness.
\end{abstract}

\section{Keywords}

Senior Manager Compensation, Salaries of Full-Time Employees in Non-Management Positions, Corporate Governance Evaluation System, Differences between Senior Manager Compensation and Salaries of Full-Time Employees in Non-Management Positions 


\section{Introduction}

The outbreak of a series of financial statement fraud cases in Taiwan and other places, such as Enron, WorldCom, Procomp Informatics, and Rebar, the issue of corporate governance quickly regained attention. The Financial Supervisory Commission (FSC) issued a 5-year "Blueprint for Strengthening Corporate Governance in Taiwan" in December 2013. The FSC promoted the first corporate governance evaluation system in $2014^{1}$ which sought to compare listed companies' corporate governance results so that those companies would be encouraged to pay greater attention to and strengthen corporate governance. The Taiwan Stock Exchange Corporation (TWSE) ${ }^{2}$ and Taipei Exchange (TPEx) $)^{3}$ jointly entrusted the Securities Futures Institute (SFI) ${ }^{4}$ to conduct an "Evaluation of corporate governance system of listed companies". The publication of the evaluation results would help companies compete and strengthen their level of corporate governance and naturally push corporate governance into corporate organizational culture. This would thereby enhance the overall level of corporate governance, enable all listed companies to gradually improve and implement more effective corporate governance, and assist investors and enterprises to better understand the effectiveness of corporate governance implementation. It is expected that corporate governance evaluation system, through regulation evaluation and indicator identification, market mechanisms such as media, shareholders, and the publication of evaluation results, allow companies to actively review their internal risks and improve their corporate governance to establish a more determined and effective plan ${ }^{6}$. In 2006, the United States Securities and Exchange Commission (SEC) regarded the remuneration of senior managers as the top priority of corporate governance and required listed companies to disclose their overall compensation of executives and board members, Taiwan also exposed the remuneration table for directors, supervisors, and general managers. Past studies have indicated that in the rapidly changing environment of the global economy, the executive occupies the highest position in the management of organizations that plays an important strategic and decision-maker role (Holmstrom, 1979; Lazear \& Rosen, 1981). In Taiwan, all sectors of society have

\footnotetext{
${ }^{1}$ In 2015, the FSC announced the results of the first corporate governance evaluation system in 2014 as one of the bases for the adjustment of corporate management decisions within the company and the decision-making for the benefit of the investment public. It is a regulation for evaluating the quality of corporate governance.

${ }^{2}$ Taiwan Stock Exchange Corporation, Corporate Governance Center, Corporate Governance Evaluation System: https://cgc.twse.com.tw/frontEN/index

${ }^{3}$ Taipei Exchange, Corporate Governance, Corporate Governance Evaluation System: https://www.tpex.org.tw/web/regular_emerging/governance/corporate_governance_09.php?l=zh-tw ${ }^{4}$ Securities and Futures Institute, Corporate Governance, Corporate Governance Evaluation System: https://www.sfi.org.tw/cga/cga1

${ }^{5}$ Taiwan Stock Exchange Corporation, Corporate Governance Center, Corporate Governance Evaluation System: https://cgc.twse.com.tw/front/evaluationOverview

${ }^{6}$ The "First Corporate Governance Evaluation system" of Taiwan listed companies has been processed since 2014. The evaluation structure mainly includes five major aspects, namely "Maintenance of Shareholders' Equity", "Equal Treatment of Shareholders", and "Board Structure and Operation", "Information Transparency" and "Corporate Social Responsibility” (Cheng, 2015).
} 
been concerned about and discussed the issue of low salaries for entry-level employees. The salary of a top-level manager has always been widely discussed and its orientation should not only focus on social equity but also on the decisions about how to allocate corporate resources by top-level managers. Whether high salaries paid to managers by a company contributes to the firm's performance is also a focus, many studies have found that executive compensation is strongly correlated with company performance (Sun \& Cahan, 2009; Lin et al., 2013; Huang et al., 2016).

Facing the problem of low wages in Taiwan and given companies' high revenue, one asks the question: Why are employees still low-paid? In 2019, the FSC stipulated that listed companies must publish employee salaries ${ }^{7}$ and, for the first time, revealed the salaries of all employees of listed companies, including the salaries of full-time employees in non-management positions. This not only made well-paying companies transparent but also made low salary company information public. Taiwan's employee wages are important information, and this is the first time that listed companies in various industries declared salary information and subsequently had that information officially certified. Since May 2019, according to FSC regulations, listed companies must disclose employee salary information. Listed companies are forced to disclose the average salary status of "full-time employees in non-management positions" in June 2019 which signifies that companies are willing to pay higher salaries to treat employees better, which is a significant component of corporate governance ${ }^{8}$. After the salaries of employees of listed companies are disclosed, the FSC would also include this information as one of the evaluation items for corporate governance. The FSC first announced the average employee salary of listed companies in 2019, the TWSE and TPEx will further require all companies to announce the "median" employee salary in 2020 since averages are more susceptible to extreme values. After the figures are announced, the salary distribution of the employees of each listed company will be clearer and make it easier for investors and job seekers to judge a company's salary payment status.

Since 2000, the Taiwanese government has actively followed the legal regulation of US corporate governance and has gradually revised the Company Act and Securities and Exchange Law to introduce and standardize corporate governance-related mechanisms. Taiwan revised the "Guidelines for Recording Items in the Annual Reports of Public Companies" in 2004, requiring public companies to disclose in detail the salaries of their senior managers in the firm's annual report so that report users can better understand senior managers' remuneration situations. It is expected that the remuneration structure of company managers

\footnotetext{
${ }^{7}$ According to the regulations of the Financial Supervisory Commission, listed companies must report the annual salary information of employees. https://mops.twse.com.tw/mops/web/t100sb15 ${ }^{8}$ At the end of June 2019, the Market Observation Post System set up "Corporate Social Responsibility Related Information/Employee Benefits and Salary Statistics Related Information/Senior Manager Compensation and the Salaries of Full-Time Employees in Non-Management Positions" in the "Corporate Governance Zone". Users can search by different sorting functions such as securities code, industry category, or average salary cost. https://mops.twse.com.tw/mops/web/t100sb15
} 
can be regulated and implemented with market mechanisms. Corporate governance stabilizes capital markets and protects investors. Besides, Lin et al. (2012) pointed out that the more managers are paid and the better the corporate governance mechanism, the higher the level of cash dividends a company will distribute. Since compensation regulation, as far as listed companies are concerned, is an important component of corporate governance and risk management, it is an additional social responsibility. In Taiwan, some companies have suffered losses with their operations, but directors, supervisors, and managers still receive high salaries which are not only unreasonable but also affect shareholders' equity. Therefore, this research is different from previous research on executive compensation and company performance because of this added element. In 2019, the Public Information Observatory disclosed the "the salaries of full-time employees in non-management positions" for the first time, Taiwan has not yet studied the impact on corporate governance of the difference between senior manager compensation and the salaries of full-time employees in non-management positions. Therefore, this study uses the corporate governance evaluation system as a measurement variable for corporate governance to examine the impact of the difference between senior manager compensation and the salaries of full-time employees in non-management positions (DME) on the corporate governance evaluation system (CGES). The purpose of the research is to verify whether a company's salary level for managers is caused by DME or the performance of corporate governance evaluation. It also verifies whether it promotes the consistency of benefits to company insiders, outsiders, and improves the supervision to balance mechanism of a company's governance structure. Additionally, the research is supplemented by information about the inspection of Big 4 CPA firms, types of conglomerate control, and lead and concurring CPA rotation to compare the impact of DME and verify that a larger DME can encourage employees, create better performance, and affect CGES.

Except for the introduction, the structure of this article is as follows: Section 2 provides literature review and hypothesis development; Section 3 reports the research method; Section 4 provides the empirical results, and finally summarizes the conclusions and recommendations.

\section{Literature Review and Hypothesis Development}

Taiwan Stock Exchange Corporation (TWSE) and Taipei Exchange (TPEx) jointly entrust the Securities Futures Institute (SFI) conduct "Evaluation of corporate governance system of listed companies", the publication of evaluation results can help enterprises to positively compete and strengthen the level of corporate governance. The corporate governance evaluation system promotes the initial evaluation of quantitative standards and will continue to add qualitative indicators and improve standards for various indicators that he is scoring requirements of the setting.

The corporate governance evaluation system has won the attention of listed 
companies and Taiwan has earned outstanding results such as the Asian Corporate Governance Association (ACGA) and RobecoSam. Various statistical data show that Taiwan's corporate governance has been significantly improved and the results have also been recognized by international institutions (Hsieh, 2019). In terms of $\mathrm{c}$ promoting corporate governance, FSC has legalized many corporate governance concepts in the past 10 years, and based on the development trend of international corporate governance, and regarding Taiwan's corporate governance practices, it has released the "2013 Blueprint for Strengthening Corporate Governance in Taiwan", and the first corporate governance evaluation was announced in April 2015. In the future, the remuneration information of directors, supervisors, and senior managers of listed companies will be more transparent, which is expected to bring greater pressure on the remuneration decisions of listed companies, especially loss-making companies. A company should actively communicate the basis of decision-making with employees from the perspective of remuneration philosophy and policy and assist supervisors at all levels to deliver correct and consistent messages. At the same time, a company should review its overall remuneration policy and implementation promptly to meet both current corporate governance trends and its own operational needs. Corporate governance culture has not yet been popularized. The external world still believes that Taiwan's promotion of corporate governance is from top to bottom, rather than an internalization of the enterprise into its culture. It is necessary for the three parties of enterprise, media, and investors to collectively shape Taiwan's corporate governance culture for the better. The regulation for employee salary disclosure of listed companies, except for all employee benefits and average salaries disclosed in 2019, is necessary to further disclose the median salaries of full-time employees in non-management positions for corporate governance in 2020. The rankings have significant influence on companies for recruiting talent and they will put pressure on lower-ranked companies. This will hopefully create a virtuous circle in Taiwan's low-paid environment which is one of the FSC main purposes for the ranking's announcement.

Financial statements are one of the key tools for rational investors to make investment judgments and decisions. After the Asian Financial Crisis in 1997, a series of financial statement fraud cases occurred in Taiwan and other places (such as Enron, WorldCom, and Procomp Informatics). As a result, the trust by investors and the public in a company's financial statements and corporate accountants declined. This meant that there are problems with companies' internal management and corporate governance. Since the outbreak of fraud with financial statements, investors, the public and competent authorities have devoted attention to issues such as corporate governance. After the outbreak of the Global Financial Crisis in 2008, shareholders' equity suffered damage, but the companies' directors, supervisors, and senior managers still received generous remuneration. Issues have arisen in Taiwan and other places about whether companies' compensation to directors, supervisors, and senior managers are reasona- 
ble. Currently, only Huang (2020) found that the greater the gap between executive compensation and salaries of full-time employees in non-management positions, the more likely a company's salary regulation will give higher-level employees a higher level of salary. The size and complexity of customers require auditors, and a company invests significantly in auditing costs that need to provide auditors with high-quality financial reports and data sources requires higher audit fees. The impact of DME on corporate governance, however, has not yet been studied. Previous studies have shown that Big 4 auditors were characterized by higher audit quality, as demonstrated by their propensity to other audit report modifications (Francis \& Yu, 2009; Geiger \& Rama, 2006; Menon \& Williams, 2004). Therefore, this research first proposes that financial reports that are audited by Big 4 CPA firms are highly credible and play the role of an external supervision mechanism for corporate governance. The financial statements are audited by Big 4 CPA firms, so there are better corporate governance effects. This study uses corporate governance evaluation requirement indicators as a measure of corporate governance and therefore expects that the larger the DME, the better the CGES standard. This article anticipates that the DME has a positive relationship with the CGES. Accordingly, this research establishes the following hypotheses:

$\mathrm{H}_{1-\mathrm{a}}$ : The DME has a positive relationship with the CGES.

$\mathrm{H}_{1-\mathrm{b}}$ : The DME is associated with the CGES under Big 4 CPA firms.

Khanna and Rivkin (2001) believed that "Group" referred to a group of companies with similar or identical behaviors based on formal or informal agreements and were legally constituted independent entities. Differences in ownership structure can affect the demand for audit quality (Lin \& Lin, 2016). In addition, Lou and Lin (2011) pointed out that Taiwan's family businesses typically outperform non-family businesses. The Taiwan Economic Journal (TEJ) refers to a group as related enterprises based on the provisions of a special chapter of the Company Act ${ }^{9}$. This chapter refers to independent companies as those that have mutual control, subordinated relationships, and invest stakes in one other. The type of control of the ultimate entity has always been one of the more common research variables in corporate governance research. Therefore, the TEJ began to collect and organize relevant data in 2006 and officially launched the "Group Control Type" in corporate governance module in $2007^{10}$. ${ }^{9}$ Article 369-9 of the Company Act.

10"Ultimate owners" refers to the group that holds the most shares and has the greatest influence on the company's decision-making, The types can be divided into: 1) Government control; 2) Single family business control; 3) Manager governance and 4) Co-governance four types of control. The government control: The ultimate owners of the company are the local government or the central government. Single family business control: The ultimate owners of the company consist of a group of people (natural person) with the same benefits and goals, and this group of people has a "Kindred" with each other. Manager governance: The company has no obvious major shareholders, or although there are major shareholders, major shareholders do not directly participate in the company's operations and decision-making. The company's major policies are led by the manager (the ultimate owners). Co-governance: The ultimate owners of the company are composed of two or more groups (maybe families, groups, or the government). These individual groups cannot unilaterally lead the company's operations and important decisions without cooperating with other groups. 
This research refers to the "TEJ Taiwan Economic Journal-Corporate Governance Module Explanation-Group Control Type: Government control, Single family business control, Manager governance, and Co-governance" for Taiwanese enterprise groups. Control type classification applies DME to analyze whether different types of enterprise control influence corporate governance evaluation system. The following hypotheses are developed:

\section{$\mathrm{H}_{2-\mathrm{a}}$ : The DME is related to CGES in government control. \\ $\mathrm{H}_{2-\mathrm{b}}$ : The DME is related to CGES in single family business control. \\ $\mathrm{H}_{2-c}$ : The DME is related to CGES in manager governance. \\ $\mathrm{H}_{2-\mathrm{d}}$ : The DME is related to CGES in co-governance.}

In 2009, the Public Company Accounting Oversight Board (PCAOB) formulated Auditing Standard No. 7: Engagement Quality Review, which regulates the Qualifications of the Engagement Quality Reviewer about the duty of the second CPA. An audit team's audit process, judgment, and conclusion must be reviewed for overall quality after the assessment of no major defects has been found. A Concurring Approval of Issuance can be provided, and the CPA firm can only issue an audit opinion report to a client under investigation to further improve audit quality with this new requirement. In recent years, many studies have shown that the personal characteristics of accountants will affect audit quality (Gul et al., 2013; Aobdia et al., 2015). As a result, many countries around the world have required companies to disclose the names of the CPAs in audit reports ${ }^{11}$. The audit environment in Taiwan is different than other places. In 1983, Taiwan regulated that a CPA shall handle the financial report audit approval criteria for a public company. This stipulates that a public company's financial report must be signed by two CPAs, called the Dual-Signature Requirement. In Taiwan's auditing practice, the two CPAs are distinguished between a lead CPA and a concurring $\mathrm{CPA}^{12}$. Therefore, the audit opinion report of the financial statements will show the CPA firm name and the names of the two CPAs ${ }^{13}$. The so-called lead CPA refers to the CPA who substantively reviewed the audited company's financial statements. The concurring CPA conducts a written review of the evidence found without substantive review (Chen et al., 2012). The planning and execution of audit work contracting is the main responsibility of the lead CPA and the concurring CPA is typically only engaged during the review of the audit. Also, the dividend requirement is typically based on the lead CPA and the concurring CPA only receives a limited allowance (Lee et al., 2013). In short, the CPA mentioned in this article refers to the lead CPA. This CPA performs

${ }^{11}$ CPA means Certified Public Accountant.

${ }^{12}$ The signature of CPA in the audit report is from top to bottom that top is lead CPA and left to right that left is lead CPA (Chin \& Chi, 2009; Chi \& Chin, 2011; Lee et al., 2013; Liao et al., 2013).

${ }^{13}$ Taiwan CPA Associations held a public hearing in the Legislative Yuan on March 30, 2010, advocating that the current double-signature requirement for public company financial statements was changed to a single-signature requirement. However, Chen et al. (2012) pointed out that in Taiwan's current double-signature requirement, Taiwan should maintain CPA has audit responsible more than single-signature requirement, and the results of the research tend to be the dual-signature requirement that. 
fieldwork on the front line and communicates the results of inspections with clients. The concurring CPA is responsible for reviewing work papers and are more susceptible to adjustments or changes due to internal manpower planning by the firm. Compared to the concurring CPA, the quality of the lead CPA's inspection is therefore more likely to affect a customer's choice.

Auditor rotation is a significant and long-term problem in accounting firms. Practitioners and researchers have long noted that firms lose the costs of training employees who leave the firm. Recently, many in the auditing field have recognized that employee turnover may reduce audit quality. In past studies related to the tenure of CPAs, there were differing opinions on whether rotation regulation should be implemented. Because long-term cooperation between CPAs and audit clients may reduce audit quality, Hoyle (1978) proposed implementing a mandatory CPA rotation. If a CPA conducts audits for the same company over a long period, the CPA's audit quality will decline, and their independence may be lost. If CPA rotation regulation is adopted and a $\mathrm{CPA}$ is regularly replaced, they will pay greater attention to auditing public expenses and resist any pressure exerted by a client. The CPA, however, may not be familiar with the characteristics of the industry, which may reduce the efficiency of the audit and lead to poor corporate governance. Myers et al. (2003) identified that longer CPA tenures maintain better quality audits. This research therefore considers Taiwan's unique dual-signature requirement and further divides lead CPA and concurring CPA to explorer CGES is affected by the rotation of the lead $\mathrm{CPA}^{14}$ or the concurring $\mathrm{CPA}^{15}$ within 7 years. This study establishes the following hypotheses:

$\mathrm{H}_{3-2}$ : During the change of lead CPA, DME is related to the CGES.

$\mathrm{H}_{3-\mathrm{b}}$ : During the non-change of lead CPA, DME is related to the CGES.

$\mathrm{H}_{3-c}$ : During the change of concurring CPA, DME is related to the CGES.

$\mathrm{H}_{3-\mathrm{d}}$ : During the non-change of concurring CPA, DME is related to the CGES.

\section{Research Method}

\subsection{Sample Selection}

The main purpose of this research is to explore the relationship between the corporate governance evaluation system and the natural log of the difference between senior manager compensation and the salaries of full-time employees in non-management positions, which will change corporate governance evaluation system grades. Because the Financial Supervisory Commission publicly disclosed

${ }^{14} 1$ if lead CPA has rotation and 0 otherwise. Both lead CPA and concurring CPA certification for 5 consecutive years is equal to 1; from 2004 to 2007, any CPA certification for 5 consecutive years are equal to 1; from 2008, any CPA certification for 7 consecutive years is equal to 1 . Data source: Taiwan Economic Journal (TEJ). https://www.tej.com.tw/webtej/plus/wcparpta.htm

${ }^{15} 1$ if concurring CPA has rotation and 0 otherwise. Both lead CPA and concurring CPA certification for 5 consecutive years is equal to 1 ; from 2004 to 2007, any CPA certification for 5 consecutive years are equal to 1; from 2008, any CPA certification for 7 consecutive years is equal to 1 . Data source: Taiwan Economic Journal (TEJ). https://www.tej.com.tw/webtej/plus/wcparpta.htm 
the average salaries of "full-time employees in non-management positions" for the first time in June 2019, this study selected all listed companies in Taiwan in 2019 as the sample. There is a total of 1554 companies that have been evaluated but 487 observations without one complete year of financial data are eliminated which brings the total sample size to 1067. Relevant financial data include corporate governance information, audit firm data, and signing auditor names from the Taiwan Economic Journal database (TEJ). The Taiwan Market Observation Post System data identified 1067 annual financial filings made by listed companies during the sample period.

Panel A in Table 1 presents the distribution of Big 4 CPA firms and Corporate governance evaluation system used by research samples. It shows that the proportion of CGES companies using Big 4 CPA firms is 88.75 percent (947/1067), whereas only 11.25 percent (120/1067) of the sample's companies used non-Big 4 CPA firms. The Deloitte category is 40.76 percent $(386 / 947)$. CGES with 8 point for the top $5 \%$ is 4.87 percent (52/1067), 7 point for $6 \%$ to $20 \%$ is 15.37 percent (164/1067), and 6 point for $21 \%$ to $35 \%$ is 14.71 percent (157/1067). Panel B presents the samples falling into the category of single family business control companies are 59.14 percent (631/1067). Panel C in Table 1 distinguishes between types of conglomerate control and Big 4 CPA firms' companies. It reveals the number of dominate single family business control companies that are audited by Big 4 CPA firms is $51.17 \%$ (546/1067), which indicates that the majority of listed companies are family-owned enterprises and they overwhelmingly trust the audit quality of Big 4 CPA firms.

Finally, Panel D shows the distribution of the dual-signature requirement according to the type of lead CPA and concurring CPA rotation. Sample companies dominated by the dual-signature requirement are as follows: Lead CPA rotation companies are 8.15 percent, non-lead CPA rotation companies are 91.85 percent, concurring CPA rotation companies are 6.47 percent, non-concurring CPA rotation companies are 93.53 percent regardless of lead CPA or concurring CPA. CPA rotation accounts for most of the proportion.

\subsection{Research Design and Proxies}

\section{Empirical Models}

This study describes how the natural log of the difference between senior manager compensation and salaries of full-time employees in non-management positions in Taiwanese listed companies will affect corporate governance. This study uses a corporate governance evaluation system as a measure of corporate governance. Because the CGES indicator has different levels, this article uses an ordered probit model regression to test the model (1). This article also refers to past literature and incorporates factors that may affect the CGES control in the model. The regression model (1) of this study is as follows:

$$
\begin{aligned}
\text { CGESi.t }= & \beta_{0}+\beta_{1} \mathrm{DME}_{i, t}+\beta_{2} \mathrm{SIZE}_{i, t}+\beta_{3} \mathrm{DE}_{i, t}+\beta_{4} \mathrm{ROA}_{i, t}+\beta_{5} \mathrm{DP}_{i, t}+\beta_{6} \mathrm{BHold}_{i, t} \\
& +\beta_{7} \mathrm{MHold}_{i, t}+\beta_{8} \mathrm{PDM}_{i, t}+\beta_{9} \mathrm{AGE}_{i, t}+\beta_{10} \text { Foreign }_{i, t}+\beta_{11} \text { National }_{i, t}+\varepsilon_{i, t}
\end{aligned}
$$


Table 1. Sample distribution.

\begin{tabular}{|c|c|c|c|c|c|c|c|c|}
\hline \multicolumn{9}{|c|}{ Pane A: Distribution of Big 4 CPA firms and corporate governance evaluation system (CGES) } \\
\hline $\begin{array}{c}\text { Types of CPA firms }{ }^{b} \\
\text { CGES }^{\mathrm{a}}\end{array}$ & Big 4 & $\begin{array}{l}\text { Non- } \\
\text { Big } 4\end{array}$ & Total & Deloitte & PWC & KPMG & EY & Total \\
\hline 1 & $\begin{array}{c}53 \\
(4.97 \%)\end{array}$ & $\begin{array}{c}14 \\
(1.31 \%)\end{array}$ & $\begin{array}{c}67 \\
(6.28 \%)\end{array}$ & $\begin{array}{c}22 \\
(2.32 \%)\end{array}$ & $\begin{array}{c}14 \\
(1.48 \%)\end{array}$ & $\begin{array}{c}9 \\
(0.95 \%)\end{array}$ & $\begin{array}{c}8 \\
(0.84 \%)\end{array}$ & $\begin{array}{c}53 \\
(5.60 \%)\end{array}$ \\
\hline 2 & $\begin{array}{c}146 \\
(13.68 \%)\end{array}$ & $\begin{array}{c}32 \\
(3.00 \%)\end{array}$ & $\begin{array}{c}178 \\
(16.68 \%)\end{array}$ & $\begin{array}{c}62 \\
(6.55 \%)\end{array}$ & $\begin{array}{c}30 \\
(3.17 \%)\end{array}$ & $\begin{array}{c}40 \\
(4.22 \%)\end{array}$ & $\begin{array}{c}14 \\
(1.48 \%)\end{array}$ & $\begin{array}{c}146 \\
(15.42 \%)\end{array}$ \\
\hline 3 & $\begin{array}{c}106 \\
(9.93 \%)\end{array}$ & $\begin{array}{c}19 \\
(1.78 \%)\end{array}$ & $\begin{array}{c}125 \\
(11.72 \%)\end{array}$ & $\begin{array}{c}46 \\
(4.86 \%)\end{array}$ & $\begin{array}{c}19 \\
(2.01 \%)\end{array}$ & $\begin{array}{c}22 \\
(2.32 \%)\end{array}$ & $\begin{array}{c}19 \\
(2.01 \%)\end{array}$ & $\begin{array}{c}106 \\
(11.19 \%)\end{array}$ \\
\hline 4 & $\begin{array}{c}133 \\
(12.46 \%)\end{array}$ & $\begin{array}{c}27 \\
(2.53 \%)\end{array}$ & $\begin{array}{c}160 \\
(15.00 \%)\end{array}$ & $\begin{array}{c}57 \\
(6.02 \%)\end{array}$ & $\begin{array}{c}30 \\
(3.17 \%)\end{array}$ & $\begin{array}{c}33 \\
(3.48 \%)\end{array}$ & $\begin{array}{c}13 \\
(1.37 \%)\end{array}$ & $\begin{array}{c}133 \\
(14.04 \%)\end{array}$ \\
\hline 5 & $\begin{array}{c}147 \\
(13.78 \%)\end{array}$ & $\begin{array}{c}17 \\
(1.59 \%)\end{array}$ & $\begin{array}{c}164 \\
(15.37 \%)\end{array}$ & $\begin{array}{c}62 \\
(6.55 \%)\end{array}$ & $\begin{array}{c}29 \\
(3.06 \%)\end{array}$ & $\begin{array}{c}37 \\
(3.91 \%)\end{array}$ & $\begin{array}{c}19 \\
(2.01 \%)\end{array}$ & $\begin{array}{c}147 \\
(15.52 \%)\end{array}$ \\
\hline 6 & $\begin{array}{c}153 \\
(14.34 \%)\end{array}$ & $\begin{array}{c}4 \\
(0.37 \%)\end{array}$ & $\begin{array}{c}157 \\
(14.71 \%)\end{array}$ & $\begin{array}{c}65 \\
(6.86 \%)\end{array}$ & $\begin{array}{c}47 \\
(4.96 \%)\end{array}$ & $\begin{array}{c}25 \\
(2.64 \%)\end{array}$ & $\begin{array}{c}16 \\
(1.69 \%)\end{array}$ & $\begin{array}{c}153 \\
(16.16 \%)\end{array}$ \\
\hline 7 & $\begin{array}{c}157 \\
(14.71 \%)\end{array}$ & $\begin{array}{c}7 \\
(0.66 \%)\end{array}$ & $\begin{array}{c}164 \\
(15.37 \%)\end{array}$ & $\begin{array}{c}51 \\
(5.39 \%)\end{array}$ & $\begin{array}{c}45 \\
(4.75 \%)\end{array}$ & $\begin{array}{c}43 \\
(4.54 \%)\end{array}$ & $\begin{array}{c}18 \\
(1.90 \%)\end{array}$ & $\begin{array}{c}157 \\
(16.58 \%)\end{array}$ \\
\hline 8 & $\begin{array}{c}52 \\
(4.87 \%)\end{array}$ & $\begin{array}{c}0 \\
(0.00 \%)\end{array}$ & $\begin{array}{c}52 \\
(4.87 \%)\end{array}$ & $\begin{array}{c}21 \\
(2.22 \%)\end{array}$ & $\begin{array}{c}12 \\
(1.27 \%)\end{array}$ & $\begin{array}{c}15 \\
(1.58 \%)\end{array}$ & $\begin{array}{c}4 \\
(0.42 \%)\end{array}$ & $\begin{array}{c}52 \\
(5.49 \%)\end{array}$ \\
\hline Total & $\begin{array}{c}947 \\
(88.75 \%)\end{array}$ & $\begin{array}{c}120 \\
(11.25 \%)\end{array}$ & $\begin{array}{c}1067 \\
(100 \%)\end{array}$ & $\begin{array}{c}386 \\
(40.76 \%)\end{array}$ & $\begin{array}{c}226 \\
(23.86 \%)\end{array}$ & $\begin{array}{c}224 \\
(23.65 \%)\end{array}$ & $\begin{array}{c}111 \\
(11.72 \%)\end{array}$ & $\begin{array}{c}947 \\
(100.00 \%)\end{array}$ \\
\hline
\end{tabular}

\begin{tabular}{|c|c|c|c|c|c|c|c|c|c|}
\hline $\begin{array}{c}\text { CGES } \\
\text { Types of conglomerate control }\end{array}$ & 1 & 2 & 3 & 4 & 5 & 6 & 7 & 8 & Total \\
\hline Government control & $\begin{array}{c}1 \\
(0.09 \%)\end{array}$ & $\begin{array}{c}2 \\
(0.19 \%)\end{array}$ & $\begin{array}{c}0 \\
(0.00 \%)\end{array}$ & $\begin{array}{c}0 \\
(0.00 \%)\end{array}$ & $\begin{array}{c}6 \\
(0.56 \%)\end{array}$ & $\begin{array}{c}7 \\
(0.66 \%)\end{array}$ & $\begin{array}{c}7 \\
(0.66 \%)\end{array}$ & $\begin{array}{c}2 \\
(0.19 \%)\end{array}$ & $\begin{array}{c}25 \\
(2.34 \%)\end{array}$ \\
\hline Single family business control & $\begin{array}{c}38 \\
(3.56 \%)\end{array}$ & $\begin{array}{c}120 \\
(11.25 \%)\end{array}$ & $\begin{array}{c}84 \\
(7.87 \%)\end{array}$ & $\begin{array}{c}97 \\
(9.09 \%)\end{array}$ & $\begin{array}{c}94 \\
(8.81 \%)\end{array}$ & $\begin{array}{c}94 \\
(8.81 \%)\end{array}$ & $\begin{array}{c}84 \\
(7.87 \%)\end{array}$ & $\begin{array}{c}20 \\
(1.87 \%)\end{array}$ & $\begin{array}{c}631 \\
(59.14 \%)\end{array}$ \\
\hline Manager governance & $\begin{array}{c}17 \\
(1.59 \%)\end{array}$ & $\begin{array}{c}38 \\
(3.56 \%)\end{array}$ & $\begin{array}{c}26 \\
(2.44 \%)\end{array}$ & $\begin{array}{c}38 \\
(3.56 \%)\end{array}$ & $\begin{array}{c}44 \\
(4.12 \%)\end{array}$ & $\begin{array}{c}44 \\
(4.12 \%)\end{array}$ & $\begin{array}{c}56 \\
(5.25 \%)\end{array}$ & $\begin{array}{c}26 \\
(2.44 \%)\end{array}$ & $\begin{array}{c}289 \\
(27.09 \%)\end{array}$ \\
\hline Co-governance & $\begin{array}{c}11 \\
(1.03 \%)\end{array}$ & $\begin{array}{c}18 \\
(1.69 \%)\end{array}$ & $\begin{array}{c}15 \\
(1.41 \%)\end{array}$ & $\begin{array}{c}25 \\
(2.34 \%)\end{array}$ & $\begin{array}{c}20 \\
(1.87 \%)\end{array}$ & $\begin{array}{c}12 \\
(1.12 \%)\end{array}$ & $\begin{array}{c}17 \\
(1.59 \%)\end{array}$ & $\begin{array}{c}4 \\
(0.37 \%)\end{array}$ & $\begin{array}{c}122 \\
(11.43 \%)\end{array}$ \\
\hline Total & $\begin{array}{c}67 \\
(6.28 \%)\end{array}$ & $\begin{array}{c}178 \\
(16.68 \%)\end{array}$ & $\begin{array}{c}125 \\
(11.72 \%)\end{array}$ & $\begin{array}{c}160 \\
(15.00 \%)\end{array}$ & $\begin{array}{c}164 \\
(15.37 \%)\end{array}$ & $\begin{array}{c}157 \\
(14.71 \%)\end{array}$ & $\begin{array}{c}164 \\
(15.37 \%)\end{array}$ & $\begin{array}{c}53 \\
(4.97 \%)\end{array}$ & $\begin{array}{c}1067 \\
(100 \%)\end{array}$ \\
\hline
\end{tabular}

\begin{tabular}{|c|c|c|c|c|c|c|c|}
\hline \multicolumn{8}{|c|}{ Pane C: Distribution of types of conglomerate control and Big 4 CPA firms } \\
\hline \multicolumn{2}{|c|}{$\begin{array}{c}\text { Types of conglomerate control } \\
\text { Types of CPA firms }\end{array}$} & Government control & \multicolumn{2}{|c|}{$\begin{array}{l}\text { Single family business } \\
\text { control }\end{array}$} & $\begin{array}{l}\text { Manager } \\
\text { governance }\end{array}$ & Co-governance & Total \\
\hline \multicolumn{2}{|c|}{ Big4 } & $\begin{array}{c}24 \\
(2.25 \%)\end{array}$ & & $\begin{array}{c}546 \\
(51.17 \%)\end{array}$ & $\begin{array}{c}271 \\
(25.40 \%)\end{array}$ & $\begin{array}{c}106 \\
(9.93 \%)\end{array}$ & $\begin{array}{c}947 \\
(88.75 \%)\end{array}$ \\
\hline \multicolumn{2}{|c|}{ Non-Big4 } & $\begin{array}{c}1 \\
(0.09 \%)\end{array}$ & & $\begin{array}{c}85 \\
(7.97 \%)\end{array}$ & $\begin{array}{c}18 \\
(1.69 \%)\end{array}$ & $\begin{array}{c}16 \\
(1.50 \%)\end{array}$ & $\begin{array}{c}120 \\
(11.25 \%)\end{array}$ \\
\hline \multicolumn{2}{|c|}{ Total } & $\begin{array}{c}25 \\
(2.34 \%)\end{array}$ & & $\begin{array}{c}631 \\
(59.14 \%)\end{array}$ & $\begin{array}{c}289 \\
(27.09 \%)\end{array}$ & $\begin{array}{c}122 \\
(11.43 \%)\end{array}$ & $\begin{array}{c}1067 \\
(100 \%)\end{array}$ \\
\hline \multicolumn{8}{|c|}{ Pane D: Distribution of dual-signature requirement } \\
\hline $\begin{array}{l}\text { Dual-signature } \\
\text { requirement }\end{array}$ & $\begin{array}{c}\text { Change of lead } \\
\text { CPA }\end{array}$ & $\begin{array}{l}\text { Non-change of } \\
\text { lead CPA }\end{array}$ & Total & $\begin{array}{r}\text { Change } \\
\text { concurring }\end{array}$ & $\begin{array}{l}\text { of } \\
\text { CPA }\end{array}$ & $\begin{array}{l}\text {-change of } \\
\text { arring CPA }\end{array}$ & Total \\
\hline Total & $\begin{array}{c}87 \\
(8.15 \%)\end{array}$ & $\begin{array}{c}980 \\
(91.85 \%)\end{array}$ & $\begin{array}{c}1067 \\
(100 \%)\end{array}$ & $\begin{array}{c}69 \\
(6.47 \%)\end{array}$ & & $\begin{array}{l}998 \\
93.53 \%)\end{array}$ & $\begin{array}{c}1067 \\
(100 \%)\end{array}$ \\
\hline
\end{tabular}

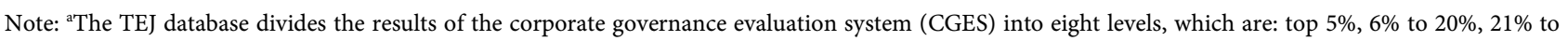
$35 \%, 36 \%$ to $50 \%, 51 \%$ to $65 \%, 66 \%$ to $80 \%, 81 \%$ to $100 \%$. Insufficient data that are not included in the evaluation have been replaced in this research with scores of 8 to 1 , with 8 point for the top $5 \%, 7$ point for $6 \%$ to $20 \%, 6$ point for $21 \%$ to $35 \%$, and so on. $81 \%$ to $100 \%$ are given 2 point and companies with insufficient data that not included in the evaluation are given 1 point. 
where:

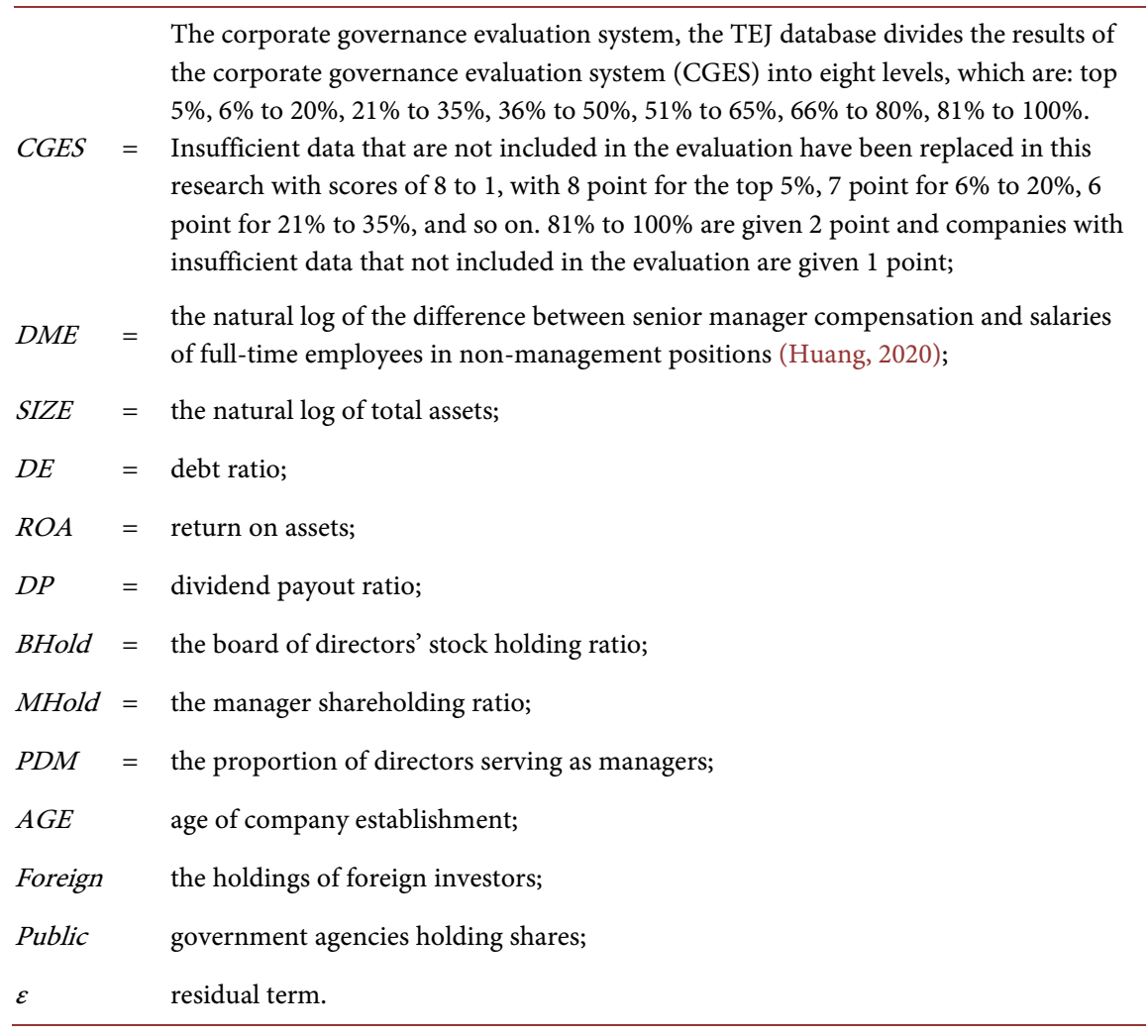

\subsection{Related Variables and Operational Definitions}

\subsubsection{Dependent Variable: Corporate Governance Evaluation System (CGES)}

The evaluation indicators of Taiwan's corporate governance evaluation system are designed to protect the rights and benefits of shareholders, uphold stockholders' equity, strengthen the structure and operation of the board of directors, enhance information transparency, and implement corporate social responsibility. The structure of the evaluation indicator is based mainly on the six principles of corporate governance issued in 2004 by the Organization for Economic Co-operation and Development (OECD), and adjust it to the five major aspects of corporate governance evaluation system indicators "Maintaining the interests of shareholders", "Treating shareholders equally", "Strengthening the structure and operation of the board of directors", "Improving information transparency" and "Implementing corporate social responsibility", and in line with the OECD corporate governance principles promulgated in 2015. In the fifth index, the dimensions of "Shareholders' equity" and "Equal treatment of shareholders" were combined and adjusted to four dimensions. This study divides the results of the 6th CGES in 2019 into eight levels, which are: Top 5\%, 6\% to $20 \%, 21 \%$ to $35 \%$, $36 \%$ to $50 \%, 51 \%$ to $65 \%, 66 \%$ to $80 \%, 81 \%$ to $100 \%$. Insufficient data that are not included in the evaluation have been replaced in this research with scores of 8 to 1 , with 8 point for the top $5 \%, 7$ point for $6 \%$ to $20 \%, 6$ point for $21 \%$ to 
$35 \%$, and so on. $81 \%$ to $100 \%$ are given 2 point and companies with insufficient data that not included in the evaluation are given 1 point.

\subsubsection{Independent Variable: The Natural Log of the Difference between Senior Manager Compensation and Salaries of Full-Time Employees in Non-Management Positions (DME)}

The Taiwan Stock Exchange Corporation hopes that listed companies attach importance to operational performance and companies should attach importance to the rights and interests of employees, improve salaries of employees, promote a win-win situation for labor-management, and implement both corporate governance and corporate social responsibility. Since 2019, Taiwan listed companies have reported "Salaries of full-time employees in non-management positions information" for the first time in $2018^{16}$. The information reported by each company must be reviewed by a CPA to audit to ensure information disclosure reliability and comparability. In addition, "Employee Benefit Expenses" and other remuneration profile information of all employees must be disclosed in the notes of the annual financial report by the end of March of each year. Listed companies should also report the "Salaries of full-time employees in non-management positions information of the previous year before the end of April." Declared items include the number of employees (excluding director of the board and managers), total salary, average salary, and median salary. Among them, the median salary is declared before the end of April 2020 and the information for 2019 will be applicable. The Stock Exchange Corporation will disclose a company's "Salaries of full-time employees in non-management positions information" at a public information observatory before the end of June each year to provide an external reference ${ }^{17}$. Currently, only Huang (2020) found that the greater the gap between executive compensation and salaries of full-time employees in non-management positions, the more likely a company's salary regulation will give higher-level employees a higher level of salary. As for the independent variable by Huang (2020) estimates it as a proxy variable.

\subsubsection{Control Variables}

This study divides control variables into financial characteristics about operating performance (ROA,DE), corporate characteristics (SIZE, $A G E)$, and corporate governance characteristics ( $D P$, BHold, MHold, PDM, Foreign, Public). Operating performance is represented by return on assets $(R O A)$ and debt ratio $(D E)$ to explore whether corporate governance is the result of different operating performance. A company may encounter different risks and, therefore, its risk pre-

\footnotetext{
${ }^{16}$ Listed companies in Taiwan have applied for "Salaries of full-time employees in non-management positions information" since 2019, https://www.twse.com.tw/zh/news/newsDetail/ff80808167ee6fdf01682c52ee3c01ca

${ }^{17}$ Regarding employee salary declaration requirements, the Taiwan Stock Exchange Corporation has conducted "Business Promotion Conferences for Listed Companies" in the fourth quarter of 2018 to strengthen publicity, and completed the "Declaration Instructions" and "Frequently Asked Questions (FAQ)" by the end of 2018, each company can go to the information reporting system (https://sii.twse.com.tw) for inquiries.
} 
mium would be different compared to other companies (Bosworth \& Rogers, 2001). Referring to past literature (Singhvi \& Desai, 1971; McConnell \& Servaes, 1990; Calantone et al., 2002; Duchin et al., 2010), this study added the natural log of total assets as a measure of company size (SIZE) and years of company establishment $(A G E)$ to measure whether there is a difference in the level of corporate governance. Additionally, this study refers to past scholars' research to add characteristics of corporate governance (Pound, 1988; McConnell \& Servaes, 1990; Finkelstein \& D'Aveni, 1994; Stulz, 1999; Matsumoto, 2002; Eng \& Mak, 2003; Schnatterly \& Johnson, 2014; Liu et al., 2015; Shih \& Huang, 2019; Liu \& Huang, $2019)$ with the dividend payout ratio $(D P)$, the board of directors' stock holding ratio (BHold), the manager shareholding ratio (MHold), the proportion of directors serving as managers ( $P D M)$, the holdings of foreign investors (Foreign), and government agencies holding shares (Public) as corporate governance control variables. The inference of the last variable is that stronger supervision of corporate governance maintains a higher relative quality of financial statements and better corporate governance.

\section{Empirical Results}

\subsection{Descriptive Statistics}

Table 2 reports descriptive statistics for the sample to analyze the relationship between the corporate governance evaluation system and the natural log of the difference between senior manager compensation and the salaries of full-time employees in non-management positions. When comparing totals, Big 4 CPA firms, and non-Big 4 CPA firms, this study finds companies with Big 4 CPA firms have higher governance evaluation systems (with a mean of 3.6072), larger $D M E$ (with a mean of 14.7924), larger company size (SIZE), higher return on assets $(R O A)$, a higher dividend payout ratio $(D P)$, a higher board of directors' stock holding ratio (BHold), a higher manager shareholding ratio (MHold), larger holdings of foreign investors (Foreign), a lower debt ratio $(D E)$, a larger proportion of directors serving as managers $(P D M)$, greater government agencies holding shares (Public), and a younger age of company establishment (AGE). In other words, companies with Big 4 CPA firms for audit effectively have better corporate governance and financial performance.

\subsection{Correlation Matrix}

Table 3 shows the Pearson correlation matrix for the research variables. This study uses the difference between senior manager compensation and the salaries of full-time employees in non-management positions effect on the corporate governance evaluation system in the regression analysis. The analysis reported in Table 3 shows that $C G E S$ is significantly positively correlated with $D M E$ (the correlation coefficient is 0.334 ), which means companies with $C G E S$ have higher $D M E$ and better corporate governance. Additionally, CGES is also significantly positively correlated with SIZE, ROA, Foreign, and Public (with Pearson coeffi- 
cients of $0.340,0.238,0.306$, and 0.159 , respectively), The proportion of directors serving as managers $(P D M)$ relationship shows a significant negative correlation (correlation coefficient of -0.070 ).

Table 2. Descriptive statistics.

\begin{tabular}{|c|c|c|c|c|c|c|c|c|c|}
\hline \multicolumn{10}{|c|}{ Distribution of Big 4 CPA firms } \\
\hline & \multicolumn{3}{|c|}{ Total sample $(\mathrm{n}=1067)$} & \multicolumn{3}{|c|}{ Big 4 CPA firms $(n=947)$} & \multicolumn{3}{|c|}{ Non-Big 4 CPA firms $(n=120)$} \\
\hline Variables $^{\mathrm{a}}$ & Mean & Median & Std. Dev & Mean & Median & Std. Dev & Mean & Median & Std. Dev \\
\hline CGES & 3.4640 & 4.0000 & 2.0106 & 3.6072 & 4.0000 & 2.0100 & 2.3417 & 2.0000 & 1.6321 \\
\hline$D M E$ & 14.7520 & 14.7598 & 0.9771 & 14.7924 & 14.7867 & 0.9830 & 14.4336 & 14.4545 & 0.8694 \\
\hline$S I Z E$ & 15.4725 & 15.2600 & 1.4868 & 15.5183 & 15.2800 & 1.4859 & 15.1114 & 15.0250 & 1.4500 \\
\hline$D E$ & 0.4105 & 0.4204 & 0.1836 & 0.4083 & 0.4176 & 0.1792 & 0.4277 & 0.4519 & 0.2147 \\
\hline$R O A$ & 0.0816 & 0.0753 & 0.0962 & 0.0861 & 0.0798 & 0.0966 & 0.0468 & 0.0540 & 0.0860 \\
\hline$D P$ & 1.2533 & 0.5981 & 18.6541 & 1.3497 & 0.6060 & 19.7988 & 0.4918 & 0.4516 & 0.6944 \\
\hline BHold & 0.2131 & 0.1708 & 0.1487 & 0.2136 & 0.1708 & 0.1502 & 0.2092 & 0.1705 & 0.1375 \\
\hline MHold & 0.0133 & 0.0041 & 0.0262 & 0.0135 & 0.0045 & 0.0264 & 0.0118 & 0.0022 & 0.0242 \\
\hline$P D M$ & 0.1907 & 0.1429 & 0.1299 & 0.1874 & 0.1429 & 0.1280 & 0.2162 & 0.2000 & 0.1420 \\
\hline$A G E$ & 32.2877 & 30.0000 & 13.5699 & 31.5343 & 30.0000 & 13.5022 & 38.2333 & 35.0000 & 12.6529 \\
\hline Foreign & 0.0135 & 0.0042 & 0.0263 & 0.1119 & 0.0531 & 0.1452 & 0.0118 & 0.0022 & 0.0242 \\
\hline Public & 0.1065 & 0.0491 & 0.1410 & 0.0090 & 0.0000 & 0.0405 & 0.0637 & 0.0275 & 0.0909 \\
\hline
\end{tabular}

${ }^{a} C G E S$ : corporate governance evaluation system; $D M E$ : the natural log of the difference between senior manager compensation and salaries of full-time employees in non-management positions; SIZE: the natural log of total assets; $D E$ : debt ratio; ROA: return on asset; $D P$. dividend payout ratio; $B H o l d$ : the board of directors' stock holding ratio; $M H o l d$ : the manager shareholding ratio; $P D M$ : the proportion of directors serving as managers; $A G E$ : age of company establishment; Foreign: h the holdings of foreign investors; Public. government agencies holding shares.

Table 3. Correlation matrix.

\begin{tabular}{|c|c|c|c|c|c|c|c|c|c|c|c|c|}
\hline Variables ${ }^{\mathrm{a}, \mathrm{b}}$ & CGES & $D M E$ & $S I Z E$ & $D E$ & $R O A$ & $D P$ & BHold & MHold & $P D M$ & $A G E$ & Foreign & Public \\
\hline CGES & 1.000 & & & & & & & & & & & \\
\hline$D M E$ & $0.334^{*}$ & 1.000 & & & & & & & & & & \\
\hline SIZE & $0.340^{*}$ & $0.411^{\star}$ & 1.000 & & & & & & & & & \\
\hline$D E$ & -0.021 & -0.030 & $0.353^{*}$ & 1.000 & & & & & & & & \\
\hline$R O A$ & $0.238^{\star}$ & $0.352^{*}$ & $0.204^{\star}$ & $-0.129^{\star}$ & 1.000 & & & & & & & \\
\hline$D P$ & -0.036 & -0.031 & -0.004 & -0.038 & -0.015 & 1.000 & & & & & & \\
\hline BHold & 0.035 & $-0.081^{*}$ & $-0.126^{*}$ & -0.048 & 0.025 & -0.026 & 1.000 & & & & & \\
\hline MHold & -0.018 & 0.037 & $-0.139^{\star}$ & -0.018 & 0.044 & -0.009 & 0.024 & 1.000 & & & & \\
\hline$P D M$ & $-0.070^{\star}$ & $0.060^{*}$ & 0.003 & 0.024 & 0.049 & 0.016 & $-0.123^{\star}$ & $0.187^{*}$ & 1.000 & & & \\
\hline$A G E$ & -0.060 & $-0.081^{\star}$ & $0.300^{*}$ & $0.126^{*}$ & -0.054 & 0.027 & $-0.092^{\star}$ & $-0.171^{*}$ & -0.033 & 1.000 & & \\
\hline Foreign & $0.306^{\star}$ & $0.407^{\star}$ & $0.445^{*}$ & 0.017 & $0.274^{*}$ & -0.018 & -0.059 & -0.048 & 0.035 & -0.047 & 1.000 & \\
\hline Public & $0.159^{*}$ & $0.099^{*}$ & $0.220^{*}$ & 0.052 & 0.042 & -0.008 & $0.112^{*}$ & -0.053 & $-0.102^{\star}$ & 0.041 & $0.090^{*}$ & 1.000 \\
\hline
\end{tabular}

${ }^{a} C G E S$ : corporate governance evaluation system; DME: the natural log of the difference between senior manager compensation and salaries of full-time employees in non-management positions; SIZE: the natural log of total assets; $D E$ : debt ratio; ROA: return on asset; $D P$. dividend payout ratio; $B H o l d$ : the board of directors' stock holding ratio; $M H o l d$ : the manager shareholding ratio; $P D M$ : the proportion of directors serving as managers; $A G E$ : age of company establishment; Foreign: h the holdings of foreign investors; Public. government agencies holding shares. ${ }^{b}$ Pearson correlations in the lower diagonal. * Indicates significance at the 5 percent level. 
The above significant correlations are all within plus or minus 0.4 , which belongs to the range of low correlation. As for other variables, there are some significant correlations, most of which are below 0.3. The correlation coefficient between SIZE and Foreign is as high as 0.45 , which signifies that the size of a company is related to the holdings by foreign investors. The highly correlated threshold of 0.7 , however, is not reached. Considering the problem of collinearity, this article uses the variance inflation factor (VIF) as an auxiliary, and the VIF value of all variables in the regression are lower than the threshold value of 10.

\subsection{Multivariate Analysis}

\subsubsection{CGES and DME}

In the Taiwan auditing market, the Big 4 CPA firms account for a large market share ${ }^{18}$. The analysis tests how the natural log of the difference between senior manager compensation and salaries of full-time employees in non-management positions $(D M E)$ will affect their corporate governance evaluation system (CGES). This article uses an ordered probit model regression to test the hypotheses to make the relevant estimations. The empirical results are shown in $\mathrm{Ta}$ ble 4. Panel A divides the sample into total samples, the Big 4 CPA firms, and non-Big 4 CPA firms. The empirical results show the coefficient of the DME is significantly positive by total samples and the Big $4 \mathrm{CPA}$ firms with estimated coefficients of $0.1600(z=4.11)$ and $0.1666(z=4.07)$, respectively. In companies with a large $D M E$, there is a significant and positive correlation with the level of CGES and this supports research $\mathrm{H}_{1-\mathrm{a}}$ and $\mathrm{H}_{1-\mathrm{b}}$. Non-Big $4 \mathrm{CPA}$ firms reached a positive but insignificant level. This means that when companies pay higher salaries to management, it encourages them to make greater efforts with the temptation of a higher salary. It also means that the larger the difference between senior manager compensation and the salaries of full-time employees in non-management positions, the more it can motivate a manager to work. This helps improve a company's overall operating performance and maintain better corporate governance standards. Compared with non-Big 4 CPA firms, the Big 4 CPA firms have more resources and professional knowledge personnel to maintain the firm's reputation provide better quality accounting information and corporate governance mechanisms.

In terms of control variables, the empirical results show that company size (SIZE), return on assets (ROA), holdings of foreign investors (Foreign), and government agencies holding shares (Public) are significantly positive in total samples and with Big 4 CPA Firms. The debt ratio $(D E)$, dividend payout ratio $(D P)$, proportion of directors serving as managers ( $P D M)$, and age of company

\footnotetext{
${ }^{18}$ According to the statistics of the Market Observation Post System on December 31, 2019, the number of clients audited by the Big 4 CPA Firms for approximately $89 \%$ of all listed companies. From the perspective of the market value of audited clients, the total market value of audited clients by the Big 4 CPA Firms that account for approximately $98 \%$ of the total market value of all listed companies. https://emops.twse.com.tw/server-java/t58query
} 
Table 4. CGES and DME-Big 4 CPA firms and Non-Big 4 CPA firms.

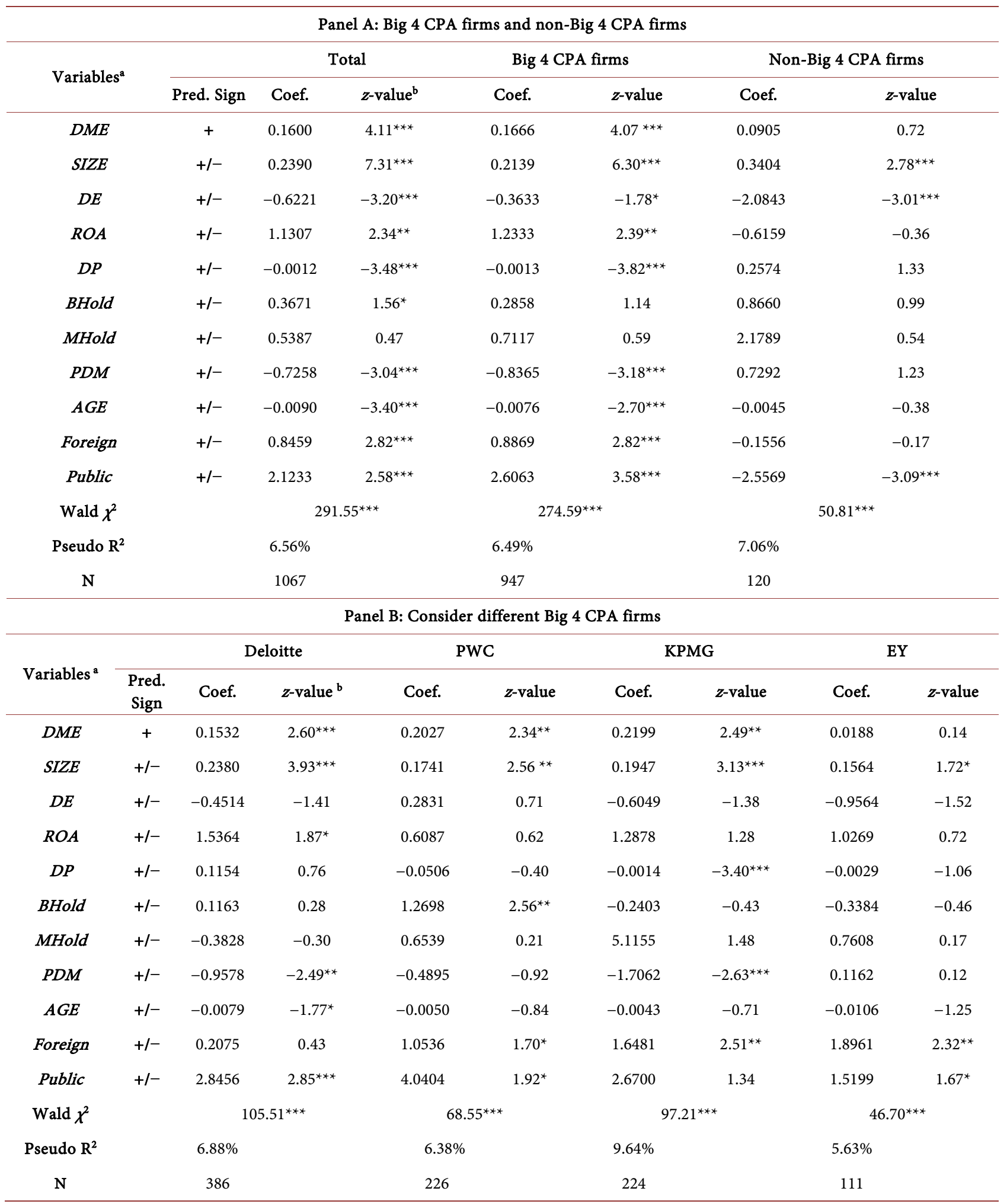

${ }^{a} D M E$ : the natural log of the difference between senior manager compensation and salaries of full-time employees in non-management positions; $S I Z E$ : the natural log of total assets; $D E$ : debt ratio; ROA: return on asset; $D P$. dividend payout ratio; BHold: the board of directors' stock holding ratio; $M H o l d$ : the manager shareholding ratio; PDM: the proportion of directors serving as managers; AGE: age of company establishment; Foreign: h the holdings of foreign investors; Public. government agencies holding shares. ${ }^{b}$ Asterisks ${ }^{*},{ }^{*},{ }^{* * *}$ indicate two-tailed significance at the $0.10,0.05$, and 0.01 levels, respectively. 
establishment $(A G E)$ show a significantly negative correlation. Companies with larger size $(S I Z E)$, return on assets $(R O A)$, and a lower debt ratio $(D E)$ are positively correlated. Larger companies reveal more information for financing considerations, which, in turn, enables the investing public to have greater confidence in the company's fundraising. This means that the company's capital structure is relatively sound, creditors have greater protection, and shareholders participate in the higher the value of a company with a sound corporate governance mechanism. The holdings of foreign investors (Foreign) and government agencies holding shares (Public) are significantly positively correlated, with the higher the shareholding ratio of institutional legal persons, the stronger the intensity of corporate governance supervision. This indicates that a better corporate governance mechanism helps improve the internal control efficiency of a company's financial operations. When companies have a lower dividend payout ratio $(D P)$, controlling shareholders have greater incentives to engage in opportunistic behavior and deprive the interests of external shareholders, leading to significant agency problems. Corporate governance, therefore, tends to be poor. The proportion of directors serving as managers $(P D M)$ is significantly negatively correlated, illustrating the agency theory that the chairman and general manager positions should not overlap. In recent years in Taiwan and internationally, the prevention of money laundering has been continuously emphasized and companies must expose "beneficial owners." These individuals may be important management or governance units within the company. The higher the proportion of directors serving as managers $(P D M)$, the less likely that corporate governance evaluation is low. Finally, the younger the age of company establishment $(A G E)$, the more likely a company's internal mechanism is better, as reflected in excellent corporate governance.

Panel B further explores the impact of the Big 4 CPA firms on CGES and divides the research samples into Deloitte, KPMG, PwC, and EY for analysis ${ }^{19}$. The empirical results show that the estimated coefficients of Deloitte, KPMG, PwC, and $D M E$ are $0.1532(z=2.60), 0.2027(z=2.34)$, and $0.2199(z=2.49)$, which are all positive and reach a level of significance. It signifies that Deloitte, KPMG, and $\mathrm{PwC}$ have a clear influence on the corporate governance mechanism during a work inspection, which, in turn, enables a company to have a better evaluation. Additionally, because EY has the lowest market share among the Big 4 CPA firms ${ }^{20}$, the results of this study show that $D M E$ of EY has no clear influence on CGES.

\footnotetext{
${ }^{19}$ Big 4 CPA Firms: Deloitte Certified Public Accountants and Touche Certified Public Accountants jointly established a new "Deloitte \& Touche", which became the international organization "Deloitte Touche Tohmatsu Limited (DTTL)" in 2003; PWC: PricewaterhouseCoopers; KPMG was merged with Peat Marwick International (PMI) and Klynveld Main Goerdeler (KMG) named KPMG in 1987; EY: Ernst \& Young. From TEJ database. https://www.tej.com.tw/webtej/plus/wcparpta.htm

${ }^{20}$ According to the statistics of the Market Observation Post System on December 31, 2019, the number of clients audited by the Big 4 CPA Firms accounted for approximately $89 \%$ of all listed companies. Among them, Deloitte, KPMG, PwC, and Ernst \& Young accounted for 40\%, 26\%, 22\%, and $11 \%$ of the Big 4 CPA Firms respectively.
} 


\subsubsection{CGES and DME: Types of Conglomerate Control}

Table 5 further divides sample companies according to the types of conglomerate control. As sub-samples, these categories include: Government control, single family business control, manager governance, and co-governance. The results shown in Table 5 indicate whether the impact of types of conglomerate control is any different on CGES.

The findings reveal that the coefficient for $D M E$ with manager governance and co-governance are $0.2788(z=3.53, p<0.01)$ and $0.3566(z=2.37, p<0.05)$, which are indicative of a significant and positive correlation with CGES. Different from government control and single family business control, co-governance companies typically have a more dispersed shareholding structure, and no single group of shares has an absolute dominant advantage. The ultimate controller must therefore seek support from other shareholders, so the board of directors will typically be controlled by more than two groups. This type of manager governance is the most common in Taiwan's electronics industry. For this type of manager governance, the ultimate controller must have a professional or technical background in addition to serving as a key director in the operation of the company and holding other important positions (General Manager, Chief Executive Officer, R\&D Supervisor, etc.). These features imply a greater $C G E S$ and there is a more cautious level of corporate governance. The empirical results show that only manager governance and co-governance are the same as the expected hypothesis. Government control and single family business control are not significant, so $\mathrm{H}_{2-\mathrm{c}}$ and $\mathrm{H}_{2-\mathrm{d}}$ are empirically supported.

Table 5. CGES and DME-Types of conglomerate control.

\begin{tabular}{|c|c|c|c|c|c|c|c|c|c|}
\hline \multirow[t]{2}{*}{ Variables $^{\mathbf{a}}$} & \multicolumn{3}{|c|}{ Government control } & \multicolumn{2}{|c|}{$\begin{array}{c}\text { Single family } \\
\text { business control }\end{array}$} & \multicolumn{2}{|c|}{$\begin{array}{l}\text { Manager } \\
\text { governance }\end{array}$} & \multicolumn{2}{|c|}{ Co-governance } \\
\hline & Pred. Sign & Coef. & $z$-value ${ }^{\text {b }}$ & Coef. & $z$-value & Coef. & $z$-value & Coef. & $z$-value \\
\hline$D M E$ & + & -0.4970 & -1.32 & 0.0717 & 1.51 & 0.2788 & $3.53^{\star * *}$ & 0.3566 & $2.37^{\star *}$ \\
\hline$S I Z E$ & $+1-$ & 1.2005 & $3.65^{\star * *}$ & 0.1942 & $4.42^{\star * *}$ & 0.2960 & $4.38^{* * *}$ & 0.0858 & 0.83 \\
\hline$D E$ & $+1-$ & 0.1857 & 0.10 & -0.8880 & $-3.39^{* * *}$ & -0.3789 & -0.96 & 0.2488 & 0.42 \\
\hline$R O A$ & $+1-$ & 8.7077 & $3.62^{\star * *}$ & 1.3074 & $2.10^{* *}$ & 0.7148 & 0.82 & 0.8980 & 0.61 \\
\hline$D P$ & $+1-$ & -1.5391 & $-1.95^{\star}$ & -0.0016 & $-6.95^{\star * *}$ & 0.0399 & $5.70^{\star * *}$ & 0.0262 & 0.66 \\
\hline BHold & $+1-$ & -4.4055 & $-1.93^{\star}$ & 0.7264 & $2.26^{\star *}$ & 0.0189 & 0.04 & 0.5940 & 0.82 \\
\hline MHold & $+1-$ & 30.0705 & 1.51 & 0.8312 & 0.40 & 0.4978 & 0.39 & -1.6709 & -0.32 \\
\hline$P D M$ & $+1-$ & -0.6139 & -0.16 & -0.6484 & $-2.12^{\star *}$ & -0.6847 & -1.47 & -2.1476 & $-2.35^{\star *}$ \\
\hline$A G E$ & $+1-$ & -0.0476 & $-2.46^{\star \star}$ & -0.0028 & -0.79 & -0.0254 & $-3.26^{* * *}$ & 0.0040 & 0.52 \\
\hline Foreign & $+1-$ & -5.0603 & -1.10 & 1.0033 & $1.85^{\star}$ & 0.1948 & 0.46 & 1.7984 & $1.77^{*}$ \\
\hline Public & $+1-$ & -0.5429 & -0.28 & 7.3270 & $2.39^{* *}$ & 3.1542 & 1.18 & 0.8687 & 0.13 \\
\hline Wald $\chi^{2}$ & & \multicolumn{2}{|c|}{$111.30^{* * *}$} & \multicolumn{2}{|c|}{$209.48^{\star * *}$} & \multicolumn{2}{|c|}{$148.61^{\star * *}$} & \multicolumn{2}{|c|}{$35.00^{* * *}$} \\
\hline Pseudo $\mathrm{R}^{2}$ & & \multicolumn{2}{|l|}{$44.62 \%$} & \multicolumn{2}{|c|}{$5.32 \%$} & \multicolumn{2}{|l|}{$10.08 \%$} & \multicolumn{2}{|l|}{$7.19 \%$} \\
\hline $\mathbf{N}$ & & \multicolumn{2}{|l|}{25} & \multicolumn{2}{|l|}{631} & \multicolumn{2}{|l|}{289} & \multicolumn{2}{|l|}{122} \\
\hline
\end{tabular}

${ }^{a} D M E$ : the natural log of the difference between senior manager compensation and salaries of full-time employees in non-management positions; SIZE: the natural log of total assets; $D E$ : debt ratio; ROA: return on asset; DP: dividend payout ratio; $B H o l d$ : the board of directors' stock holding ratio; $M H o l d$ : the manager shareholding ratio; PDM: the proportion of directors serving as managers; AGE: age of company establishment; Foreign: h the holdings of foreign investors; Public: government agencies holding shares. ${ }^{b}$ Asterisks ${ }^{*}, * *, * *$ indicate two-tailed significance at the $0.10,0.05$, and 0.01 levels, respectively. 


\subsubsection{CGES and DME: Change Lead CPA and Change Concurring CPA}

To understand whether two CPAs are simultaneously responsible or whether the dual-signature requirement has created an impact of DME on CGES, the Public Company Accounting Oversight Board (2009) identified that a signature of a CPA on an audit report may help increase accountability and transparency. Since 1983, Taiwan has required that financial statements filed with the Public Issuance Division must be audited by two CPAs and signed to certify the financial statements with jointly guaranteed responsibility (Chen et al. 2020). First, the empirical results in Table 6 shows that the $D M E$ estimation coefficient is $0.1675(z=4.24, p<0.01)$, reaching a significant level of $1 \%$. This indicates that non-change lead CPA has a positive and significant impact on CGES, supporting the hypothesis of this research. Secondly, the empirical results show a significant level of positive correlation regardless of whether there is change concurring CPA with estimated coefficients of $0.4669(z=1.94, p<0.05)$ and $0.1524(z=$ $3.81, p<0.01)$, respectively. The audit work of contracting, planning, and executing are the main responsibility of the lead CPA. Because the lead CPA may be unfamiliar with the characteristics of the industry (due to a short tenure), the efficiency of inspections may be reduced, which lead to poor corporate governance. Change lead CPA cannot therefore connect with CGES, which is what causes reasons of non-significance. The longer the tenure of a CPA (non-change lead CPA), the better the quality of an audit and corporate governance. Whether

Table 6. CGES and DME-Change lead CPA and change concurring CPA.

\begin{tabular}{|c|c|c|c|c|c|c|c|c|c|}
\hline \multirow[t]{2}{*}{ Variables $^{a}$} & \multicolumn{3}{|c|}{$\begin{array}{l}\text { Change of } \\
\text { lead CPA }\end{array}$} & \multicolumn{2}{|c|}{$\begin{array}{l}\text { Non - change } \\
\text { of lead CPA }\end{array}$} & \multicolumn{2}{|c|}{$\begin{array}{c}\text { Change of } \\
\text { concurring CPA }\end{array}$} & \multicolumn{2}{|c|}{$\begin{array}{l}\text { Non-change of } \\
\text { concurring CPA }\end{array}$} \\
\hline & Pred. Sign & Coef. & $z$-value ${ }^{\mathrm{b}}$ & Coef. & $z$-value & Coef. & $z$-value & Coef. & $z$-value \\
\hline$D M E$ & + & 0.1013 & 0.41 & 0.1675 & $4.24^{\star * \star}$ & 0.4669 & $1.94^{\star *}$ & 0.1524 & $3.81^{* \star \star}$ \\
\hline$S I Z E$ & $+1-$ & 0.0300 & 0.23 & 0.2550 & $7.59^{\star * \star}$ & 0.2191 & $1.73^{*}$ & 0.2321 & $6.89^{* * *}$ \\
\hline$D E$ & $+1-$ & -0.3413 & -0.46 & -0.6299 & $-3.12^{* * *}$ & -1.6220 & $-1.82^{\star}$ & 0.5660 & $-2.83^{* * *}$ \\
\hline$R O A$ & $+/-$ & 0.5487 & 0.22 & 1.1800 & $2.38^{\star *}$ & -0.3706 & -0.19 & 1.1724 & $2.37^{\star \star}$ \\
\hline$D P$ & $+1-$ & 0.0004 & -0.18 & -0.0013 & $-4.04^{\star * *}$ & 0.0539 & 0.53 & -0.0012 & $-3.37^{* * *}$ \\
\hline BHold & $+1-$ & -0.8621 & -1.0 & 0.4697 & $1.89^{*}$ & 0.2955 & 0.30 & 0.3550 & 1.46 \\
\hline MHold & $+1-$ & 2.2955 & 0.69 & 0.2441 & 0.21 & 7.3701 & 1.06 & 0.3331 & 0.29 \\
\hline$P D M$ & $+1-$ & -1.6915 & $-2.12^{\star *}$ & -0.6580 & $-2.60^{* * *}$ & -1.3650 & -1.30 & -0.7308 & $-2.98^{\star * *}$ \\
\hline$A G E$ & $+1-$ & -0.0003 & -0.02 & -0.0095 & $-3.47^{* * *}$ & 0.0056 & 0.44 & -0.0093 & $-3.37^{\star * *}$ \\
\hline Foreign & $+1-$ & 2.0922 & 1.61 & 0.7190 & $2.37^{\star \star}$ & -0.4253 & -0.58 & 0.9281 & $2.86^{\star * \star}$ \\
\hline Public & $+1-$ & 7.1735 & $2.05^{\star *}$ & 1.8917 & $2.29^{\star *}$ & 22.5040 & $2.49^{\star *}$ & 2.0886 & $2.56^{\star *}$ \\
\hline Wald $\chi^{2}$ & & \multicolumn{2}{|c|}{$41.18^{* * *}$} & \multicolumn{2}{|c|}{$288.19^{* * *}$} & \multicolumn{2}{|c|}{$28.78^{* * *}$} & \multicolumn{2}{|c|}{$269.83^{\star * *}$} \\
\hline Pseudo $\mathrm{R}^{2}$ & & \multicolumn{2}{|l|}{$5.39 \%$} & \multicolumn{2}{|c|}{$6.92 \%$} & \multicolumn{2}{|l|}{$0.25 \%$} & \multicolumn{2}{|l|}{$6.56 \%$} \\
\hline $\mathbf{N}$ & & \multicolumn{2}{|l|}{87} & \multicolumn{2}{|l|}{980} & \multicolumn{2}{|l|}{69} & \multicolumn{2}{|l|}{998} \\
\hline
\end{tabular}

a $D M E$ : the natural log of the difference between senior manager compensation and salaries of full-time employees in non-management positions; SIZE: the natural log of total assets; $D E$ : debt ratio; ROA: return on asset; DP: dividend payout ratio; BHold: the board of directors' stock holding ratio; $M H o l d$ : the manager shareholding ratio; PDM: the proportion of directors serving as managers; AGE: age of company establishment; Foreign: h the holdings of foreign investors; Public. government agencies holding shares. ${ }^{b}$ Asterisks ${ }^{*},{ }^{* *},{ }^{* *}$ indicate two-tailed significance at the $0.10,0.05$, and 0.01 levels, respectively. 
the change concurring CPA is changed or not, the concurring CPA typically only engages in the review of auditing work paper, which both impacts $D M E$ and CGES. At the same time, the empirical results of this research also indirectly affirm the positive effects of the "CPA Rotation" of Taiwan's Dual-Attestation Signature. The empirical results show that only change lead CPA is not significant. The empirical results of the others are the same as that which are expected, supporting $\mathrm{H}_{3-\mathrm{b}}, \mathrm{H}_{3-\mathrm{c}}$ and $\mathrm{H}_{3-\mathrm{d}}$.

\subsection{Additional Test}

Tobin's Q and DME: Big 4 CPA Firms and Non-Big 4 CPA Firms

Lindenberg and Ross (1981) stated that Tobin's Q refers to the ratio of a company's market value to the replacement cost of its tangible assets. Tobin's $Q$ considers the value of intangible assets such as company exclusivity, goodwill, and patent rights. Tobin's $\mathrm{Q}$ can therefore be used as a research variable to measure a higher firm value ${ }^{21}$. The greater the intangible assets created by a company or the greater the chance of growth, both which can be defined as a higher firm value. This study therefore adopts the approximate Tobin's Q as proposed by Chung and Pruitt (1994) to use as a substitute indicator to measure firm value ${ }^{22}$. This study therefore explores whether the difference between senior manager compensation and salaries of full-time employees in non-management positions $(D M E)$ will affect the company's operating performance. The sample is divided into Big 4 CPA firms and non-Big 4 CPA firms. Table 7 illustrates that $D M E$ is

Table 7. Tobin's Q and DME-Big 4 CPA firms and non-Big 4 CPA firms.

\begin{tabular}{cccccc}
\hline \multirow{2}{*}{ Variables $^{\mathrm{a}}$} & \multicolumn{2}{c}{ Big 4 CPA firms } & \multicolumn{2}{c}{ Non-Big 4 CPA firms } \\
\cline { 2 - 6 } & Pred. Sign & Coef. & $t$-value & Coef. & $t$-value \\
\hline CONSTANT & & 2.4496 & $3.67^{* * *}$ & 2.6506 & $3.98^{* * *}$ \\
DME & + & 0.1286 & $2.65^{* * *}$ & 0.0260 & 0.62 \\
SIZE & $+/-$ & -0.1888 & $-6.02^{* * *}$ & -0.1058 & $-2.97^{* * *}$ \\
DE & $+/-$ & -0.7066 & $-2.85^{* * *}$ & -0.3349 & -1.45 \\
ROA & $+/-$ & 0.9250 & 0.91 & 0.7782 & 1.04 \\
DP & $+/-$ & -0.0007 & $-3.90^{* * *}$ & -0.0778 & $-1.68^{*}$ \\
BHold & $+/-$ & 0.1420 & 0.75 & 0.2889 & 0.91 \\
MHold & $+/-$ & 0.9886 & 1.02 & -1.5913 & -1.42 \\
PDM & $+/-$ & -0.4764 & $-2.54^{* *}$ & -0.3778 & -1.37 \\
AGE & $+/-$ & -0.0069 & $-3.51^{* * *}$ & -0.0058 & -1.36 \\
Foreign & $+/-$ & 1.5949 & $4.41^{* * *}$ & -0.0185 & -0.05 \\
Public & $+/-$ & 3.4823 & $2.7^{* * *}$ & 1.2354 & $3.43^{* * *}$ \\
Adj. $R^{2}$ & & $20.54 \%$ & & & \\
N & & 947 & & 120 & \\
\hline
\end{tabular}

${ }^{a} D M E$ : the natural log of the difference between senior manager compensation and salaries of full-time employees in non-management positions; SIZE: the natural log of total assets; $D E$ : debt ratio; ROA: return on asset; DP. dividend payout ratio; BHold: the board of directors' stock holding ratio; $M H o l d$ : the manager shareholding ratio; PDM: the proportion of directors serving as managers; AGE: age of company establishment; Foreign: h the holdings of foreign investors; Public: government agencies holding shares. ${ }^{\mathrm{b}}$ Asterisks ${ }^{*}$, ${ }^{* *},{ }^{* *}$ indicate two-tailed significance at the $0.10,0.05$, and 0.01 levels, respectively. 
positively associated with a higher firm value (Tobin's Q) for Big 4 CPA firms, which are more likely to receive favorable reactions from market participants and increases in firm value. Users of financial statements believe that auditors' experience improves the quality of financial reporting and this is reflected with subsequent positive effects on the values of firms with Big 4 CPA auditors. The research results verify that the larger $D M E$, the more employees can be motivated to generate better performance for a better company value and performance evaluation.

\section{Conclusion}

The Taiwan Stock Exchange established the "Corporate Governance Evaluation System" following the "2013 Blueprint for Strengthening Taiwan's Corporate Governance". Since 2014, all listed companies have been evaluated and the evaluation results have been announced to promote corporate governance and promote healthy competition among companies. From the initial standardized design of evaluated quantitative indicators to improve qualitative scores, corporate governance evaluation has gradually guided listed companies to adopt better corporate governance measures through various implementations to enhance corporate governance and corporate social responsibility. The Financial Supervisory Commission mandated listed companies disclose employee salary information in May 2019. In June 2019, for the first time, listed companies disclosed average salaries of "full-time employees in non-management positions". As salary levels of employees in various industries are different, it is difficult to set standards. Companies, however, are now more willing to pay their employees higher salaries and treat them well, which is an especially important component of corporate governance. After salaries of employees of listed companies are disclosed, the FSC will also include this information as one of the items in corporate governance evaluation. Thus far, Taiwan has not studied the impact of the natural $\log$ of the difference between senior manager compensation and salaries of full-time employees in non-management positions $(D M E)$ on the corporate governance evaluation system (CGES). This article therefore takes the listed companies in Taiwan in 2019 (excluding banks and insurance companies) as the research object and explores whether greater differences between senior manager compensation and salaries of full-time employees in non-management positions create more motivated employees that generate better performance. The company's salary regulation will give higher-level employees a higher level of salary. Since treating employees is also an important component of corporate governance, companies will pay attention to and strengthen corporate gover-

${ }^{21}$ In the past, scholars studied the relationship between corporate governance ratings and corporate value, and often used Tobin's Q as a measure of corporate value (Renders et al., 2010; Black et al., 2014).

${ }^{22}$ Chung and Pruitt (1994) developed a calculation formula that uses basic financial and accounting information to calculate a formula similar to Tobin's Q, which approximates Tobin's Q = (Equity Market Value + Liabilities Market Value)/(Equity Book Value + Liabilities Book Value), then it is often regarded as a proxy variable of firm value. 
nance.

This study uses listed companies in 2019 to evaluate and explore the relationship between the $D M E$ and the corporate governance evaluation system. The corporate governance evaluation level is based on the evaluation results published by the Securities and Exchange Commission and ranges from 1 to 8 points. Using a quantitative scoring method, a higher evaluation score indicates a better corporate governance evaluation level. The empirical results of the research using the ordered probit regression model indicate that $D M E$ has a positive and significant relationship with CGES under Big 4 CPA Firms. In other words, the results of this study indicate that larger $D M E$ companies use Big 4 CPA firms. Manager governance, co-governance, non-change lead CPA, change concurring $\mathrm{CPA}$, and non-change concurring CPA show that companies have better corporate governance evaluation. A company's salary regulation will give high-level employees higher level salaries and a company's scale, risk, and customer complexity will also be higher. Therefore, improving the quality of corporate governance will bring beneficial corporate governance effects.

Since Taiwan's listed companies first reported 2018 salary information with "Salaries of full-time employees in non-management positions" starting in 2019, the "median" senior manager compensation and salaries of full-time employees in non-management positions will be disclosed starting in 2020 to allow employees of all companies to allow the salary statistics of employees of various companies more referential and comparable. This study therefore suggests that the Taiwanese supervisory agency proposes to expand the provision for disclosing salaries of full-time employees in non-management positions based on an employee's gender, education, seniority, age, and company industry. It is also expected that the future corporate governance evaluation system will not only gradually increase qualitative factors, but also publish evaluation results by industry or other classification methods to encourage companies to attach importance to corporate governance. It is helpful to enhance the international competitiveness of Taiwan's capital markets so that investors can better understand a company's financial statement information and the external supervision function of CPAs.

\section{Conflicts of Interest}

The author declares no conflicts of interest regarding the publication of this paper.

\section{References}

Aobdia, D., Lin, C. J., \& Petacchi, R. (2015). Capital Market Consequences of Audit Partner Quality. The Accounting Review, 90, 2143-2176. https://doi.org/10.2308/accr-51054

Black, B. S., De Carvalho, A. G., \& Sampaio, J. O. (2014). The Evolution of Corporate Governance in Brazil. Emerging Markets Review, 20, 176-195.

https://doi.org/10.1016/j.ememar.2014.04.004 
Bosworth, D., \& Rogers, M. (2001). Market Value, R\&D and Intellectual Property: An Empirical Analysis of Large Australia Firms. The Economic Record, 77, 323-337. https://doi.org/10.1111/1475-4932.t01-1-00026

Calantone, R. J., Cavusgil, S., \& Zhao, Y. (2002). Learning Orientation, Firm Innovation Capability, and Firm Performance. Industrial Marketing Management, 31, 515-524. https://doi.org/10.1016/S0019-8501(01)00203-6

Chen, H. L., Chang, Y. S., \& Yen, S. H. (2012). Investigating Audit Partner Signature Styles on Audit Reports: Perspectives from Judiciary Practitioners and Securities Agents. Review of Accounting and Auditing Studies, 2, 1-30.

Chen, J. Z., Chen, M. H., Chin, C. L., \& Lobo, G. J. (2020). Do Firms That Have a Common Signing Auditor Exhibit Higher Earnings Comparability? The Accounting Review, 95, 115-143. https://doi.org/10.2308/accr-52522

Cheng, T. (2015). Corporate Governance Evaluation System and Its Future Benefits. Accounting Research Monthly, 350, 68-73.

Chi, H. Y., \& Chin, C. L. (2011). Firm versus Partner Measures of Auditor Industry Expertise and Effects on Auditor Quality. Auditing: A Journal of Practice \& Theory, 30, 201-229. https://doi.org/10.2308/ajpt-50004

Chin, C., \& Chi, H. (2009). Reducing Restatements with Increased Industry Expertise. Contemporary Accounting Research, 26, 729-765. https://doi.org/10.1506/car.26.3.4

Chung, K. H., \& Pruitt, S. W. (1994). A Simple Approximation of Tobin's Q. Financial Management, 23, 70-74. https://doi.org/10.2307/3665623

Duchin, R., Matsusaka, J. G., \& Ozbas, O. (2010). When Are outside Directors Effective? Journal of Financial Economics, 96, 195-214. https://doi.org/10.1016/j.jfineco.2009.12.004

Eng, L. L., \& Mak, Y. T. (2003). Corporate Governance and Voluntary Disclosure. Journal of Accounting and Public Policy, 22, 325-345.

https://doi.org/10.1016/S0278-4254(03)00037-1

Finkelstein, S., \& D’Aveni, R. A. (1994). CEO Duality as a Double-Edged Sword: How Boards of Directors Balance Entrenchment Avoidance and Unity of Command. The Academy of Management Journal, 37, 1079-1108. https://doi.org/10.5465/256667

Francis, J. R., \& Yu, M. D. (2009). Big 4 Office Size and Audit Quality. The Accounting Review, 84, 1521-1552. https://doi.org/10.2308/accr.2009.84.5.1521

Geiger, M. A., \& Rama, D. V. (2006). Audit Firm Size and Going Concern Reporting Accuracy. Accounting Horizons, 20, 1-17. https://doi.org/10.2308/acch.2006.20.1.1

Gul, F. A., Wu, D., \& Yang, Z. (2013). Do Individual Auditors Affect Audit Quality? Evidence from Archival Data. The Accounting Review, 88, 1993-2023. https://doi.org/10.2308/accr-50536

Holmstrom, B. (1979). Moral Hazard and Observability. The Bell Journal of Economics, 10, 74-91. https://doi.org/10.2307/3003320

Hoyle, J. (1978). Mandatory Auditor Rotation: The Arguments and an Alternative. The Journal of Accountancy, 1455, 69-78.

Hsieh, H. H. (2019). New Trends in Corporate Governance Evaluation. Securities Services Review, 670, 40-43.

Huang, C. L., Chen, W. J., \& Chang, Y. T. (2016). The Effect of Moral Hazard of Core Agency Problem on the Relationship between CEO Compensation and Firm Performance. Journal of Management and Business Research, 33, 213-238.

Huang, Y. T. (2020). The Impact of the Gap between Executive Compensation and the 
Salaries of Full-Time Employees in Non-Management Positions on Audit Fees: Evidence from Taiwan. Journal of Business and Economic Management, 8, 151-167.

Khanna, T., \& Rivkin, J. W. (2001). Estimating the Performance Effects of Business Groups in Emerging Markets. Strategic Management Journal, 22, 45-74. https://doi.org/10.1002/1097-0266(200101)22:1<45::AID-SMJ147>3.0.CO;2-F

Lazear, E., \& Rosen, S. (1981). Rank-Order Tournament as Optimum Labor. Journal of Political Economy, 89, 841-864. https://doi.org/10.1086/261010

Lee, J. Z., Chen, H. C., \& Tang, L. F. (2013). Client Importance and Audit Quality: Audit-Partner Level Analysis. Journal of Contemporary Accounting, 14, 147-174.

Liao, Y. H., Sang, T. S., \& Lin, H. F. (2013). The Association between Substantial Non-Audit Services and Audit Quality: Evidence from Special Audit of Internal Control System. Taiwan Accounting Review, 9, 111-158.

Lin, D., Kuo, H. C., \& Wang, L. H. (2013). Chief Executive Compensation: An Empirical Study of Fat CAT CEOs. International Journal of Business and Finance Research, 7, 27-42. https://papers.ssrn.com/sol3/papers.cfm?abstract_id=2149110

Lin, H. L., \& Lin, C. J. (2016). Review of Studies on Audit Quality in Asia. NTU Management Review, 27, 305-362.

Lin, Y. F., Huang, L. J., \& Chen, S. Y. (2012). Executive Compensation, Corporate Governance, and Cash Dividend Policy. Sun Yat-sen Management Review, 20, 1213-1251.

Lindenberg, E. B., \& Ross, S. A. (1981). Tobin's Q Ratio and Industrial Organization. Journal of Business, 54, 1-32. https://doi.org/10.1086/296120

Liu, L. L., \& Huang, Y. T. (2019). A Study of Association between Taiwan's Corporate Governance Appraisal and Financial Performance: Evidence from Taiwan Listed Companies. International Business Research, 12, 66-75.

https://doi.org/10.5539/ibr.v12n11p66

Liu, Y., Miletkov, M. K., Wei, Z., \& Yang, T. (2015). Board Independence and Firm Performance in China. Journal of Corporate Finance, 30, 223-244. https://doi.org/10.1016/j.jcorpfin.2014.12.004

Lou, Y. C., \& Lin, Y. H. (2011). Meta-Analysis of Taiwanese Family Firms' Performances. Taiwan: Liwen Publishing Group.

Matsumoto, D. A. (2002). Management's Incentives to Avoid Negative Earnings Surprises. The Accounting Review, 77, 483-514. https://doi.org/10.2308/accr.2002.77.3.483

McConnell, J. J., \& Servaes, H. (1990). Additional Evidence on Equity Ownership and Corporate Value. Journal of Financial Economics, 27, 595-612. https://doi.org/10.1016/0304-405X(90)90069-C

Menon, K., \& Williams, D. D. (2004). Former Audit Partners and Abnormal Accruals. The Accounting Review, 79, 1095-1118. https://doi.org/10.2308/accr.2004.79.4.1095

Myers J., Myers, L. A., \& Omer, T. C. (2003). Exploring the Term of Auditor-Client Relationship and the Quality of Earnings: A Case for Mandatory Auditor Rotation? The Accounting Review, 78, 779-799. https://doi.org/10.2308/accr.2003.78.3.779

Pound, J. (1988). Proxy Contests and the Efficiency of Shareholder Oversight. Journal of Financial Economics, 20, 237-265. https://doi.org/10.1016/0304-405X(88)90046-3

Renders, A., Gaeremynck, A., \& Sercu, P. (2010). Corporate-Governance Ratings and Company Performance: Across-European Study. Corporate Governance: An International Review, 18, 87-106. https://doi.org/10.1111/j.1467-8683.2010.00791.x

Schnatterly, K., \& Johnson, S. G. (2014). Independent Boards and the Institutional Investors that Prefer Them: Drivers of Institutional Investor Heterogeneity in Governance 
Preferences. Strategic Management Journal, 35, 1552-1563.

https://doi.org/10.1002/smj.2166

Shih, T. L., \& Huang, Y. T. (2019). The Relationship between Corporate Governance Evaluation, CEO Turnover and Discretionary Accruals-Evidence from Taiwan. International Journal of Economics and Research, 10, 38-50.

http://www.ijeronline.com/documents/volumes/2019/Nov\%20-\%20Dec\%202019/ijer\% 20v10\%20i6\%20nd(3).pdf

Singhvi, S. S., \& Desai, H. B. (1971). An Empirical Analysis of the Quality of Corporate Financial Disclosure. The Accounting Review, 46, 129-138.

Stulz, R. M. (1999). Globalization of Equity Markets and the Cost of Capital. Journal of Applied Corporate Finance, 12, 8-25.

https://doi.org/10.1111/j.1745-6622.1999.tb00027.x

Sun, J., \& Cahan, S. (2009). The Effect of Compensation Committee Quality on the Association between CEO Cash Compensation and Accounting Performance. Corporate Governance: An International Review, 17, 193-207.

https://doi.org/10.1111/j.1467-8683.2008.00726.x 